\title{
Inhibition of Human Low Density Lipoprotein and High Density Lipoprotein Oxidation by Oligostilbenes from Rhubarb
}

\author{
Tran Minh Ngoc, ${ }^{a}$ Tran Manh Hung, ${ }^{a}$ Phuong Thien Thuong, ${ }^{a}$ MinKyun NA,${ }^{a}$ HongJin KIm, ${ }^{a}$ \\ Do Thi HA, ${ }^{a}$ Byung-Sun Min, ${ }^{b}$ Pham Thi Hong MinH, ${ }^{c}$ and KiHwan BAE ${ }^{*, a}$ \\ ${ }^{a}$ College of Pharmacy, Chungnam National University; Daejeon 305-764, Korea: ${ }^{b}$ College of Pharmacy, Catholic \\ University of Daegu; Gyeongsan 712-702, Korea: and ${ }^{c}$ Institute of Chemistry, Vietnamese Academy of Science and \\ Technology; Hanoi, Vietnam. Received February 12, 2008; accepted May 1, 2008; published online June 17, 2008
}

The objective of the present study was to elucidate the beneficial properties of ampelopsine $B(1)$ and $\varepsilon$ Viniferin (2), two oligostilbenes isolated from rhubarb, toward cardiovascular disease by protecting human lipoproteins against lipid peroxidation. In low density lipoprotein (LDL) oxidation, both 1 and 2 exert an inhibitory activity against $\mathrm{Cu}^{2+}$-, 2,2'-azobis-(2-amidinopropane) hydrochloride (AAPH)-induced, as exhibited by prolongation of lag time from 52 to 118 and $136 \mathrm{~min}$, respectively, and also increasing the lag time 38 to 105 and $128 \mathrm{~min}$ in high density lipoprotein (HDL) oxidation for 1 and 2 , respectively, at the concentration of $3.0 \mu_{\mathrm{M}}$. In generation of thiobarbituric acid reactive subtances (TBARS), compounds 1 and 2 inhibited LDL oxidation mediated by either catalytic $\mathrm{Cu}^{2+}$ or thermo-labile radical initiator (AAPH) in a dose-dependent manner with $\mathrm{IC}_{50}$ values of 3.6 and $6.0 \mu \mathrm{M}$ for 1 , and 1.7 and $3.2 \mu \mathrm{M}$ for 2 , respectively. In addition, compounds $1-2$ also showed strong ability to protect HDL oxidation induced by both $\mathrm{Cu}^{2+}$ and $\mathrm{AAPH}$ with low $\mathrm{IC}_{50}$ values. The results suggest that oligostilbenes 1-2 may have a role in preventing lipoprotein oxidation.

Key words rhubarb; ampelopsin B; $\varepsilon$-Viniferin; lipoprotein

Lipoproteins and lipoprotein oxidation play an important role in development, progression, and pathobiochemistry in many age-related disorders, such as atherosclerosis, cardiovascular disease, coronary heart disease, and aging in general, by free radical attack and reactive oxygen species to lipids, proteins, and DNA. ${ }^{1-3)}$ Numerous prospective cohort investigations have demonstrated the high density lipoprotein (HDL) plasma levels are inversely correlated with coronary artery disease and the risk of atherosclerosis. ${ }^{4,5)}$ The protective effects of HDL include reverse cholesterol transport, anti-inflammatory and antioxidative actions by protecting low density lipoprotein (LDL) from oxidation via its main Apo A-I and antioxidant enzymes. ${ }^{6-8)}$ Oxidatively modified LDL within the arterial wall or in serum is believed to be readily taken up by macrophages leading to the formation of lipid laden foam cells, with possible build-up of atherosclerotic plaque, ${ }^{9)}$ and may cause thrombosis. ${ }^{10)}$ Atherosclerosis arterial wall contain increased levels of copper and iron ions which contribute to the oxidation of lipoproteins by the generation of free radicals. ${ }^{11)} \mathrm{A}$ beneficial effect of antioxidants on reactive oxygen species generation in vitro has been clearly demonstrated, ${ }^{12)}$ although in vivo studies still lack conclusive results. ${ }^{7)}$

As a part of our screening program to find antioxidant compounds from natural sources, we have attempted to determine the human lipoprotein oxidation inhibitory constituents of Korean medicinal plants. Rhubarb is the rhizomes of Rheum undulatum L., R. palmatum., $R$. tanguticum Maxiм., $R$. officinale BAILL., and $R$. coreanum NAKAI, an important and well-known medicinal origin plant which has been used in traditional medicine for the treatment of blood stagnation and as well as a purgative agent. ${ }^{13)}$ Previously, a number of natural stilbene and anthraquinone derivatives were identified as the main components with many biological activities such as anti-inflammatory, anti-diabetic, anti-allergic, cytotoxicity, anti-carcinogenic and antioxidant. ${ }^{14-17)}$ Among them, am-

* To whom correspondence should be addressed. e-mail: baekh@cnu.ac.kr pelopsin B (1) and $\varepsilon$-Viniferin (2) are the oligostilbenes with dimer-stilbene skeleton, which was shown to have inhibitory activity against cyclooxygenase, lipoxygenase, and tyrosinase. ${ }^{18,19)}$ However, the protective effect on human lipoproteins against lipid peroxidations has not been studied. The aim of this investigation was to examine whether oligostilbenes $(\mathbf{1}, \mathbf{2})$ inhibit LDL and HDL oxidation in vitro over a wide physiological and pharmacological range. LDL and HDL oxidation was induced by copper ion $\left(\mathrm{Cu}^{2+}\right)$ and azoinitiator (AAPH), and the subsequent increase in conjugated diene formation and in lipid peroxidation products was monitored.

\section{MATERIALS AND METHODS}

Plant Material The cultivated Korean rhubarb rhizome was purchased in July 2006 from the Yuseong herbal drug market, Daejeon, Korea, and identified by Professor KiHwan Bae. A voucher specimen (CNU-1345) has been deposited in the herbarium of the College of Pharmacy, Chungnam National University, Korea.

Extraction and Isolation The dried and milled rhizomes of rhubarb $(4.7 \mathrm{~kg})$ were extracted with 201 ethanol, three times. The ethanol extract was combined and concentrated to yield a residue $(650 \mathrm{~g})$, which was suspended in water and then successively partitioned with hexane, ethyl acetate (EtOAc) and butanol $(\mathrm{BuOH})$ to afford $32.7 \mathrm{~g}$ hexane-, $308 \mathrm{~g}$ EtOAc-, and $108 \mathrm{~g} \mathrm{BuOH}$-soluble fractions, respectively.

The EtOAc-soluble fraction was diluted with acetone, and then filter through filter paper to give precipitated powder $(\mathrm{E} 1,20.7 \mathrm{~g})$ and acetone fraction $(\mathrm{E} 2,226.1 \mathrm{~g})$. The E2 $(100 \mathrm{~g})$ was subjected to silica gel column chromatography, and eluted with $\mathrm{CHCl}_{3}-\mathrm{MeOH}(80: 1$ to $0: 1)$ to separate into six fractions $(\mathrm{E} 2.1-\mathrm{E} 2.6)$. The E2.6 was chromatographed on silica gel column with $\mathrm{CHCl}_{3}-\mathrm{MeOH}(5: 1$ to 
$0: 1)$ to divide into five fractions (E2.6.1-E2.6.5). Fraction E2.6.3 was further subjected to MPLC [ODS, $250 \times 10 \mathrm{~mm}$ i.d., $\left.\mathrm{MeOH}-\mathrm{H}_{2} \mathrm{O}(35: 75)\right]$ to furnish compounds $1(76 \mathrm{mg})$ and $2(37 \mathrm{mg})$.

Ampelopsin B (1): Pale brown powder, mp: $205-207^{\circ} \mathrm{C}$; $[\alpha]_{\mathrm{D}}^{25}+170.4^{\circ}(c=0.10, \mathrm{MeOH})$; UV $\lambda_{\max }(\mathrm{MeOH}): 224$ and $281 \mathrm{~nm}$; IR $v_{\max }(\mathrm{KBr}) \mathrm{cm}^{-1}: 3340,1590,1510,1150,970$; ${ }^{1} \mathrm{H}-\mathrm{NMR}\left(400 \mathrm{MHz}\right.$, accetone- $\left.d_{6}\right) \delta: 7.09(2 \mathrm{H}, \mathrm{d}, J=8.7 \mathrm{~Hz}$, $\mathrm{H}-2,6), 6.93\left(2 \mathrm{H}, \mathrm{d}, J=8.4 \mathrm{~Hz}, \mathrm{H}-2^{\prime}, 6^{\prime}\right), 6.76(2 \mathrm{H}, \mathrm{d}$, $\left.J=8.4 \mathrm{~Hz}, \mathrm{H}-3^{\prime}, 5^{\prime}\right), 6.63(2 \mathrm{H}, \mathrm{d}, J=8.7 \mathrm{~Hz}, \mathrm{H}-3,5), 6.42$ $(1 \mathrm{H}, \mathrm{d}, J=2.1 \mathrm{~Hz}, \mathrm{H}-12), 6.32\left(1 \mathrm{H}, \mathrm{d}, J=1.8 \mathrm{~Hz}, \mathrm{H}-14^{\prime}\right), 6.22$ $(1 \mathrm{H}, \mathrm{d}, J=2.1 \mathrm{~Hz}, \mathrm{H}-10), 6.05\left(1 \mathrm{H}, \mathrm{d}, J=2.1 \mathrm{~Hz}, \mathrm{H}-12^{\prime}\right), 5.72$ $(1 \mathrm{H}, \mathrm{d}, J=11.4 \mathrm{~Hz}, \mathrm{H}-7), 5.21\left(1 \mathrm{H}, \mathrm{t}, J=3.9 \mathrm{~Hz}, \mathrm{H}-7^{\prime}\right), 4.17$ $(1 \mathrm{H}, \mathrm{d}, J=11.4 \mathrm{~Hz}, \mathrm{H}-8), 3.57(1 \mathrm{H}, \mathrm{dd}, J=3.9,17.5 \mathrm{~Hz}, \mathrm{H}-$ $\left.8^{\prime}\right), 3.20\left(1 \mathrm{H}\right.$, br d, $\left.J=17.4 \mathrm{~Hz}, \mathrm{H}-8^{\prime}\right) .{ }^{13} \mathrm{C}-\mathrm{NMR}(100 \mathrm{MHz}$, acetone- $\left.d_{6}\right) \delta$ : $160.5\left(\mathrm{C}-13^{\prime}\right), 158.8(\mathrm{C}-4), 158.6(\mathrm{C}-13)$, 157.2 (C-11'), 156.7 (C-13), 156.1 (C-11), 142.7 (C-9'), $138.2\left(\mathrm{C}-1^{\prime}\right), 134.8$ (C-9), $131.1(\mathrm{C}-1), 130.1\left(\mathrm{C}-2^{\prime}, 6^{\prime}\right)$, 128.6 (C-2, 6), 122.9 (C-14), 119.1 (C-10'), $116.1(\mathrm{C}-3,5)$, 115.6 (C-3', 5'), 109.1 (C-14'), 105.5 (C-10), 101.6 (C-12), 95.8 (C-12'), 88.4 (C-7), 49.4 (C-8), 35.9 (C-7'), 33.9 (C-8').

$\varepsilon$-Viniferin (2): Pale brown powder, mp: $149-151^{\circ} \mathrm{C}$; $[\alpha]_{\mathrm{D}}^{25}-47.0^{\circ}(c=0.5, \mathrm{MeOH}) ; \mathrm{UV} \lambda_{\max }(\mathrm{MeOH}): 220,304$ and $319 \mathrm{~nm}$; IR $v_{\max }(\mathrm{KBr}) \mathrm{cm}^{-1}: 3340,1610,1570,1510$, $1330,1260,1160 ;{ }^{1} \mathrm{H}-\mathrm{NMR}\left(400 \mathrm{MHz}\right.$, accetone- $\left.d_{6}\right) \delta: 7.21$ $\left(2 \mathrm{H}, \mathrm{d}, J=8.4 \mathrm{~Hz}, \mathrm{H}-2^{\prime}, 6^{\prime}\right), 7,17(2 \mathrm{H}, \mathrm{d}, J=8.4 \mathrm{~Hz}, \mathrm{H}-2,6)$, $6.91\left(1 \mathrm{H}, \mathrm{d}, J=16.2 \mathrm{~Hz}, \mathrm{H}-7^{\prime}\right), 6.83\left(2 \mathrm{H}, \mathrm{d}, J=8.7 \mathrm{~Hz}, \mathrm{H}-3^{\prime}\right.$, $\left.5^{\prime}\right), 6.74(2 \mathrm{H}, \mathrm{d}, J=8.7 \mathrm{~Hz}, \mathrm{H}-3,5), 6.74(1 \mathrm{H}$, overlap, H$\left.14^{\prime}\right), 6.71\left(1 \mathrm{H}, \mathrm{d}, J=16.2 \mathrm{~Hz}, \mathrm{H}-8^{\prime}\right), 6.33(1 \mathrm{H}, \mathrm{d}, J=2.1 \mathrm{~Hz}$, $\left.\mathrm{H}-12^{\prime}\right), 6.25$ (3H, brs, H-10, 12, 14). ${ }^{13} \mathrm{C}-\mathrm{NMR}(100 \mathrm{MHz}$, acetone- $\left.d_{6}\right) \delta: 162.5\left(\mathrm{C}-4^{\prime}\right), 159.9(\mathrm{C}-11,13), 159.6\left(\mathrm{C}-11^{\prime}\right)$, 157.7 (C-4, 13') 147.5 (C-9), 136.5 (C-9'), 133.9 (C-1), $130.2\left(\mathrm{C}-7^{\prime}\right), 129.9\left(\mathrm{C}-1^{\prime}\right), 128.7\left(\mathrm{C}-2^{\prime}, 6^{\prime}\right), 128.0(\mathrm{C}-2,6)$, $123.6\left(\mathrm{C}-8^{\prime}\right), 119.9\left(\mathrm{C}-10^{\prime}\right), 116.4(\mathrm{C}-3,5), 116.2\left(\mathrm{C}-3^{\prime}, 5^{\prime}\right)$, 107.1 (C-10, 14), 104.3 (C-14'), 102.2 (C-12), 96.9 (C-12'), 93.9 (C-7), 57.2 (C-8).

LDL and HDL Preparation Blood from healthy normolipemic donors was obtained by venipuncture and collected in EDTA-containing vacutainer tubes. LDL was prepared from plasma by sequential flotation ultracentrifugation as described previously. ${ }^{20)}$ To isolate HDL, plasma was prepared by centrifugation at $3000 \mathrm{rpm}$ for $10 \mathrm{~min}$ and thereafter used for the preparation of plasma lipoproteins. HDL was isolated from plasma by ultracentrifugation for $1.5 \mathrm{~h}$ with a vertical rotor. ${ }^{21)}$ After dialysis at $4{ }^{\circ} \mathrm{C}$ for $24 \mathrm{~h}$ against $10 \mathrm{~mm}$ phosphate-buffered saline (PBS) pH 7.4, HDL protein concentration $(\mathrm{mg}$ protein $/ \mathrm{ml}$ ) was determined as described by Lowry et al. 22 )

$\mathrm{Cu}^{2+}$ Mediated HDL, LDL Oxidation The oxidation of lipoproteins was assessed by the formation of conjugated dienes determined as the change in UV absorbance at $232 \mathrm{~nm}$. Briefly, HDL $(150 \mu \mathrm{g} / \mathrm{ml})$ or LDL $(150 \mu \mathrm{g} / \mathrm{ml})$ in PBS (pH 7.4) was pre-incubated with either the absence (control) or presence of tested compounds, and then $\mathrm{Cu}^{2+}(5 \mu \mathrm{M})$ was added to initiate the oxidation at $37^{\circ} \mathrm{C}$. Absorbance at $232 \mathrm{~nm}$ was continuously monitored at $10 \mathrm{~min}$ intervals for $5 \mathrm{~h}$ at $37^{\circ} \mathrm{C}$ using a pectrophotometer (Shimadzu UV-1240, Tokyo, Japan). The lag time was measured as the intercept between the baseline and the tangent of the absorbance curve during the propagation phase. ${ }^{23)}$

The oxidation of LDL or HDL to malondialdehyde (MDA) was measured using the thiobarbituric acid reactive substances (TBARS) assay. Briefly, lipoproteins $(100 \mu \mathrm{g} / \mathrm{ml})$ in PBS ( $\mathrm{pH}$ 7.4) were pre-incubated with various concentrations of tested compounds, and then $\mathrm{Cu}^{2+}$ was added to initiate the oxidation. The reaction mixture was incubated at $37^{\circ} \mathrm{C}$ for $3 \mathrm{~h}$ and the reaction was terminated by adding $20 \%$ trichloroacetic acid (TCA) and 1\% thiobarbituric acid (TBA). After boiling at $95^{\circ} \mathrm{C}$ for $15 \mathrm{~min}$, the mixture was centrifuged at $5000 \mathrm{rpm}$ for $10 \mathrm{~min}$. The absorbance of supernatant was measured at $532 \mathrm{~nm}$.

Peroxyl Radicals Mediated Human Lipoproteins Oxidation The oxidation of lipoprotein by peroxyl radicals was performed by incubation of the HDL or LDL $(150 \mu \mathrm{g} / \mathrm{ml})$ at $37^{\circ} \mathrm{C}$ in PBS (pH 7.4) with one of the thermo-labile radical initiators (AAPH) for $3 \mathrm{~h}$. AAPH $(10 \mu \mathrm{M})$ served as a source of hydrophilic peroxyl radicals. At the end of the incubation, samples were also assessed by measuring accumulation of lipid aldehydes (TBARS) as described above.

Statistical Analysis The results are expressed as mean values S.D. Statistical analysis was performed using oneway ANOVA. A $p<0.05$ was considered statistically significant.

\section{RESULTS AND DISCUSSION}

Repeated column chromatography of the EtOAc-soluble fraction of the EtOH extract of rhubarb led to the isolation of two oligostilbenes $\mathbf{1}$ and $\mathbf{2}$ (Fig. 1). Their structures of isolated compounds were identified as ampelopsin B (1) ${ }^{24)}$ and $\varepsilon$-Viniferin (2) ${ }^{25,26)}$ by comparison of physical chemistry data previously reported.

In this study, we attempted to examine their protective LDL and HDL against oxidation induced by $\mathrm{Cu}^{2+}$ and AAPH. The oxidation of human lipoproteins was assessed by the formation of MDA using TBARS assay. As shown in Table 1, both oligostilbenes $\mathbf{1}$ and $\mathbf{2}$ were strongly inhibitory against lipid peroxidation by not only metal ion $\mathrm{Cu}^{2+}$-induced but also peroxyl radical AAPH-induced in HDL with $\mathrm{IC}_{50}$ values of 3.9 and $8.2 \mu \mathrm{M}$ for $\mathbf{1}$, and 2.4 and $5.7 \mu \mathrm{M}$ for $\mathbf{2}$, respectively. A comparison with positive controls showed Vitamin $\mathrm{E}$ inhibitive effect with $\mathrm{IC}_{50}$ values exhibiting the activity of 4.3 and $10.2 \mu \mathrm{M}$, under $\mathrm{Cu}^{2+}$ and AAPH mediated oxidations, respectively. Interestingly, it was demonstrated that compounds $\mathbf{1}$ and $\mathbf{2}$ also exhibited significantly inhibitory activity against the oxidation of LDL initiated by $\mathrm{Cu}^{2+}$ in a dose-dependent manner, with $\mathrm{IC}_{50}$ values of 3.0 and $1.7 \mu \mathrm{M}$, respectively. Subsequently, under AAPH mediated oxidation, it also exhibited LDL-oxidation protective activities with $\mathrm{IC}_{50}$ values of 6.1 and $3.2 \mu \mathrm{M}$, respectively. Oth-
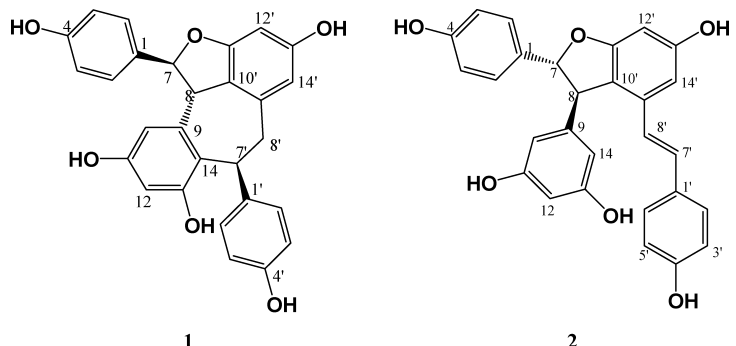

Fig. 1. Chemical Structures of Isolated Compounds $\mathbf{1}$ and $\mathbf{2}$ 
Table 1. Effect of Tested Compounds on LDL-, HDL-oxidation by TBARS Method

\begin{tabular}{|c|c|c|c|c|c|c|}
\hline \multirow{3}{*}{ Compounds } & \multicolumn{3}{|c|}{ LDL-oxidation } & \multicolumn{3}{|c|}{ HDL-oxidation } \\
\hline & \multirow{2}{*}{$\begin{array}{l}\text { Lag time } \\
\quad(\min )\end{array}$} & \multicolumn{2}{|c|}{ TBARS, $\mathrm{IC}_{50}(\mu \mathrm{M})^{a)}$} & \multirow{2}{*}{$\begin{array}{l}\text { Lag time } \\
\text { (min) }\end{array}$} & \multicolumn{2}{|c|}{ TBARS, $\mathrm{IC}_{50}(\mu \mathrm{M})^{a)}$} \\
\hline & & $\mathrm{Cu}^{2+}$-mediated & AAPH-mediated & & $\mathrm{Cu}^{2+}$-mediated & AAPH-mediated \\
\hline DMSO & 52 & & & 38 & & \\
\hline Ampelopsine B (1) & 118 & $3.0 \pm 1.2 *$ & $6.1 \pm 1.8^{*}$ & 105 & $3.9 \pm 1.2 *$ & $8.2 \pm 2.0^{*}$ \\
\hline$\varepsilon$-Viniferin (2) & 136 & $1.7 \pm 1.0^{*}$ & $3.2 \pm 1.3 *$ & 128 & $2.4 \pm 1.1 *$ & $5.7 \pm 1.9^{*}$ \\
\hline Vitamin $\mathrm{E}^{b)}$ & 75 & $20.9 \pm 2.4$ & ND & 83 & $4.3 \pm 1.2$ & $10.2 \pm 1.9$ \\
\hline
\end{tabular}

a) The values present mean \pm S.D. of triplicate experiments; $b$ ) compounds used as positive control; $* p<0.05 v s$. vitamin E. ND: not determined.

erwise, in the same conditional experiment, $\alpha$-tocopherol only showed inhibitory activity in $\mathrm{Cu}^{2+}$-mediated LDL oxidation with $\mathrm{IC}_{50}$ value of $20.9 \mu \mathrm{M}$, and vitamin $\mathrm{E}$ was found to have no or only weak activity in an AAPH mediated experiment (data not shown).

In further study, the effect of $\mathbf{1}$ and $\mathbf{2}$ on the change of lag time was investigated. The formation of conjugated dienes represents the early peroxidation during lipoprotein oxidation, and the period of lag time was interpreted as the oxidation resistant capacity of LDL and HDL. The results in Fig. $2 \mathrm{~A}$ illustrate the LDL oxidation kinetics induced by $5 \mu \mathrm{M}$ $\mathrm{Cu}^{2+}$ in the absence and the presence of $3 \mu \mathrm{M}$ tested compounds. Both 1 and $\mathbf{2}$ caused a significant modification of the kinetics of LDL oxidation producing an increase of lag time to 118 and $136 \mathrm{~min}$, respectively, versus $52 \mathrm{~min}$ in control (with $1 \% \mathrm{DMSO}, \mathrm{v} / \mathrm{v}$ ), and lag phase of vitamin $\mathrm{E}$ retarded to $75 \mathrm{~min}$ (Table 1). Additionally, at low concentration, oligostilbenes $\mathbf{1}$ and $\mathbf{2}$ also exhibited strong ability to protect HDL oxidation induced by $\mathrm{Cu}^{2+}$, and achieved a significant prolongation of the lag time to 105 and $128 \mathrm{~min}$, respectively, compared with control which was 38 min (Fig. 2B). In this experiment, the lag phase of vitamin $\mathrm{E}$ increased to $83 \mathrm{~min}$ (Table 1).

Based on the oxidation theory for atheroclerosis, dietary antioxidants have attracted considerable attention as preventive and therapeutic agents. There is large body of observational studies (demiological, case-control or prospective and retrospective cohort) on the dietary antioxidant intake link to prevent cardiovascular disease progression. ${ }^{27)}$ Consumption of dietary rich phenols and polyphenols can reduce the risk of heart disease by slowing the progression of atherosclerosis principally by protecting HDL and LDL from oxidation. ${ }^{28)}$ Oligostilbenes $\mathbf{1}$ and $\mathbf{2}$ are phenolic compounds which possess five free aromatic-OH groups. These compounds have previously been tested for their antioxidant activity such as free radical scavenging and also their inhibitory effect against lipoxygenase, ${ }^{14,18)}$ which is an enzyme indicated in the participation of the LDL lipid peroxidation process during the early stage of plaque development. ${ }^{29)}$

This study reports evidence that all tested compounds have a protective capacity to different extents on $\mathrm{Cu}^{2+}$-induced oxidation of human lipoproteins. A significant increase in lag time was observed when LDL or HDL was supplemented even with a low concentration of samples $(3 \mu \mathrm{M})$. The comparable results in LDL, HDL oxidation demonstrated that oligostilbenes $\mathbf{1}$ and $\mathbf{2}$ have greater capacity to increase the lag phase of the conjugated diene process than vitamin $\mathrm{E}$ (Figs. 2A, B). In principle, the antioxidant effect was also ev-
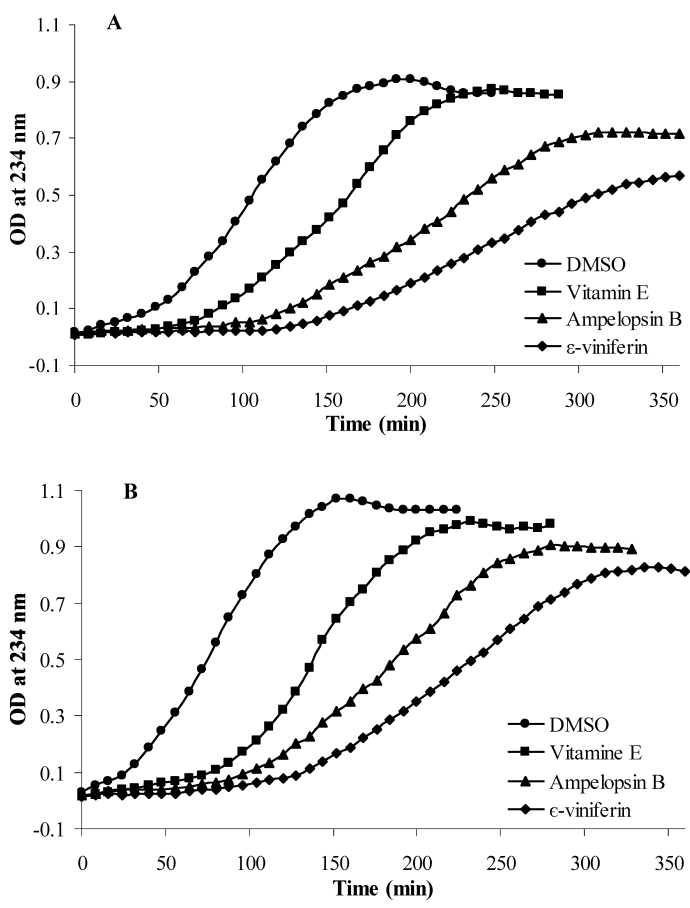

Fig. 2. Conjugated Diene Effect of Compounds $\mathbf{1}$ and $\mathbf{2}$ on the $\mathrm{Cu}^{2+}$. Mediated LDL (A) and HDL (B) Oxidation

LDL $(150 \mu \mathrm{g} / \mathrm{ml})$ or HDL $(150 \mu \mathrm{g} / \mathrm{ml})$ in PBS (pH 7.4) was incubated with $5 \mu \mathrm{M}$ $\mathrm{Cu}^{2+}$ at $37^{\circ} \mathrm{C}$ in the presence or absence of $3 \mu \mathrm{M}$ tested compounds $\mathbf{1}$ and $\mathbf{2}$, and Vitamin E. Conjugated diene was measured by determining the absorbance at $234 \mathrm{~nm}$ continuously at $8 \mathrm{~min}$ intervals for $6 \mathrm{~h}$.

ident in TBARS formation reduced by various sample concentrations after 180 min incubation. The $\mathrm{IC}_{50}$ values were established as shown in Table 1, oligostilbenes $\mathbf{1}$ and $\mathbf{2}$ were more effective antioxidant in the metal-dependent pro-oxidant system than in the peroxyl radical system, could be understood via chain-breaking mechanism by donation of phenolic hydrogen to lipoprotein bearing metal ion chelating properties. The antioxidant activities come from chemical structures themselves. Compounds $\mathbf{1}$ and $\mathbf{2}$ are dimer derivatives of resveratrol bearing mechanistic importance of the $4^{\prime}$ $\mathrm{OH}$ group, the acidity of this group and subsequent transfer of protons or hydrogen atoms to reactive species appear to be crucial to its antioxidant mechanism. All five hydroxyl hydrogens must be disordered and simultaneously act as $\mathrm{H}-$ bond donors and $\mathrm{H}$-bond acceptors to accommodate this hydrogen-bonding scheme. ${ }^{30}$ This antioxidant mechanism is used by one of the most potent phenolic antioxidants found in nature: a form of vitamin $E$ which transfers its phenolic proton to a propagating lipid peroxyl radical to terminate the 
chain reaction. ${ }^{31)}$ Ampelopsin B (1) has lost its ethylene double bond, which decreases the rotational energy for the phenyl group containing the 4'-OH group. Such information can be important for resveratrol accommodation in enzyme pockets or interaction with lipoproteins, ${ }^{31)}$ and may explain the lower antioxidant efficiency of $\mathbf{1}$ than $\varepsilon$-Viniferin (2).

There is a supposition that rhubarb could be used as an alternative therapy for heart disease, and thus oligostilbenes 1 and $\mathbf{2}$ and some other stilbenes would be able to play an important role in reducing oxidative stress, preventing the development and progression of atherosclerotic disease. In conclusion, our studies add significant evidence for the in vitro ability of ampelopsin B (1) and $\varepsilon$-Viniferin (2) to inhibit both LDL and HDL oxidation, and thus offer an additional natural antioxidant resource to prevent cardiovascular disease development.

Acknowledments This work was supported by a grant from the Korean Food and Drug Administration (2007). We are grateful to the Korean Basic Science Institute (KBSI), Daejeon, for supplying the NMR and MS spectra.

\section{REFERENCES}

1) Wilson W. P., Am. J. Hypertens., 7, 7S (1994).

2) Esterbauer H., Ramos P., Rev. Physiol. Biochem. Pharmacol., 1, 127131 (1995).

3) Hensley K., Floyd R. A., Arch. Biochem. Biophys., 397, 377-383 (2002).

4) Rubins H. B., Sander J. R., Marika K. I., William E. B., Marshall B. E., Carol L. F., David J. G., Ernst J. S., Gordon S., Janet T. W., Am. J. Cardiol., 71, 45-52 (1993).

5) von-Eckardstein A., Nofer J. R., Assmann G., Arterioscler. Thromb. Vasc. Biol., 21, 13-27 (2001).

6) Pászty C., Maeda N., Verstuyft J., Rubin E. M., J. Clin. Invest., 94, 899-903 (1994).

7) Xia P., Vadas M. A., Rye K. A., Barter P. J., Gamble J. R., J. Biol. Chem., 274, 33143-33147 (1999).

8) Navab M., Berliner J. A., Subbanagounder G., Arterioscler. Thromb.
Vasc. Biol., 21, 481-488 (2001).

9) Liu S. X., Zhou M., Chen Y., Wen W. Y., Sun M. J., Atherosclerosis, 121, 55-61 (1996).

10) Holvoet P., Collen D., FASEB J., 8, 1279-1284 (1994).

11) Berliner J. A., Haberland M. E., Curr. Opin. Lipid., 4, 373-381 (1994).

12) Cockerill G. W., Rye K. A., Gamble J. R., Vadas M. A., Barter P. J., Arterioscler. Thromb. Vasc. Biol., 15, 1987-1994 (1995).

13) Bae K. H., "The Medicinal Plants of Korea," Kyo-Hak Publishing Co., Seoul, 2001, p. 90.

14) Matsuda H., Morikawa T., Toguchida I., Park JY., Harima S., Yoshikawa M., Bioorg. Med. Chem., 9, 41-50 (2001).

15) Kim H. J., Chung S. K., Choi S. W., J. Food Sci. Nutr., 4, 163-166 (1999).

16) Sang Z. C., Sung O. L., Ki U. C., Sang H. P., Hee C. K., Eun Y. Y., Hi J. C., Kang R. L., Arch. Pharm. Res., 28, 1027-1030 (2005).

17) Song J. H., Yang T. C., Chang K. W., Han S. K., Yi H. K., Jeon J. G., Arch. Pharm. Res., 29, 490- 496 (2006).

18) Kim H. J., Ha S. C., Choi S. W., Nutraceuticals and Food, 4, 447-450 (2002).

19) Zhang Y., Jayaprakasam B., Seeram N. P., Olson L. K., DeWitt D., Nair M. G., J. Agric Food Chem., 52, 228-333 (2004).

20) Hung T. M., Na M. K., Thuong P. T., Su N. D., Sok D. E., Song K. S., Seong Y. H., Bae K. H., J. Ethnopharmacology., 108, 188-192 (2006).

21) Ferretti G., Bacchetti T., Menanno F., Curatola G., Atherosclerosis, 172, 55-61 (2004).

22) Lowry O. H., Rosebrough N. J., Farr A. L., Randall R. J., J. Biol. Chem., 193, 265-275 (1951).

23) Sobal G., Sinzinger H., Biochem. Phamacol., 70, 1185-1191 (2005).

24) Takaya Y., Yan K. X., Terashima K., Ito J., Niwa M., Tetrahedron, 58, $7259-7265$ (2002).

25) Kim H. J , Chung S. K., Choi S. W., J. Food Sci. Nutr., 4, 163-166 (1999).

26) Ito J., Takaya Y., Oshima Y., Niwa M., Tetrahedron, 55, 2529-2544 (1999).

27) Kaiora A. C., Dedoussis G. V., Schmidt H., Atherosclerosis, 187, 117 (2006).

28) Duffy S. J., Vita J. A., Curr. Opin. Lipidol., 14, 21-27 (2003).

29) Folcik V. A., Nivar-Aristy R. A., Krajewski L. P., Cathcart M. K., J. Clin. Invest. 96, 504-510 (1995).

30) Caruso F., Tanski J., Villegas-Estrada A., Rossi M., J. Agric. Food Chem., 52, 7279-7285 (2004).

31) Bowry V. R., Ingold K. U., Acc. Chem. Res., 32, 27-34 (1999). 